\title{
George S. Schuyler, Black and Conservative
}

\section{Helen Lock \\ University of Louisiana at Monroe}

When George S. Schuyler published his autobiography Black and Conservative in 1966, its title was intended to be paradoxical, underscoring how the two adjectives were rarely used together, particularly in an era that had recently seen the passage of the Civil Rights Act in 1964 and the Voting Rights Act in 1965. When it came to political affiliation, the general assumption was that African Americans, more or less by definition, were not likely to be conservatives; rather, conservatism meant a desire to preserve the pre-existing status quo, making very little sense in Civil Rights era for a majority of African Americans to take a conservative stance.

Many assumptions were and continue to be made about race, nationality or gender, but the idea that African Americans were not considered political conservatives perhaps irritated Schuyler more than any. He resented the assumption on the part of white Americans that, because he was black, he was not politically sophisticated, had 
particular interests, and, most of all, that he was a liberal, thus foisting upon him the essentialist notion that race determines politics. To Schuyler, this was the equivalent of being told how to think. In addition, as his career as a journalist and novelist developed, he increasingly adopted political views that could be characterized as right of center, a fact more than partially motivated by the desire to shock expectations. As an exception to the racial rule, Schuyler not only gained mainstream acceptance, but also the approval of renowned journalist, H. L. Mencken, whose attention he especially craved. Both Schuyler's life and work ultimately became a fascinating blurring of the authentic and the fabricated, symbolizing, in turn, his dissatisfaction with both sides of the "color line." Indeed, he underwent a very public struggle to create a self that resisted both public and private assumptions. This essay explores this dissatisfaction and struggle, focusing on two factors that were emblematic of both Schuyler's public and private lives: his satirical novel Black No More and the raising of his biracial daughter Philippa. Ultimately, Schuyler's story represents a member of an ethnic minority's siren song to conservative extremism and the self-destructiveness that came with it.

Schuyler was born in 1895 and raised in Syracuse, NY by a family that "boasted of having been free as far back as any of them could or wanted to remember, and they haughtily looked down upon those who had been in servitude... Such prejudices did not die out until after World War I" (Black and Conservative 4). His mother regarded the southern black families who had recently moved to their block as "uncouth" and associated with white Yankee families, who she described as "her kind of people" (12). He attended school as part of a tiny minority population that was "so fragmented by class divisions that any group unity was out of the question" (29), making joining the Army the only way out and upward for Schuyler. 
After service in World War I (during which he did not see combat), Schuyler found himself in Harlem, a member of the Socialist party because, in his own words, they were "[t]he most active group around town, intellectually" (113). This was perfect for the young Schuyler who was longing to discuss the most pressing political issues of the day with others. As he wrote in his biography: "I had always thought dangerously, believing there should be no limit to thought" (97). Through his party connections he became assistant editor of the Messenger, for which he also wrote a satirical column he described as "quite iconoclastic." Later, in 1924, he became the New York correspondent for the Pittsburgh Courier. By this time, Schuyler begun to "sense the proportions of what seemed [to him] to be a conspiracy to plant collectivism in America" (150). His fledgling socialism was giving way to what would soon be a fervent anticommunism, a position he took for the rest of his life.

An aversion to collectivism was a natural impulse for a man who, from the beginning of his career, took pride in bucking trends and stressed individualism. Describing his background, Schuyler wrote: "The old Northern Negro families had the habits, traits, and outlook of the whites for whom they worked and whose prejudices they shared" (4). Ironically, this claim described Schuyler himself more accurately than he was willing to recognize. One of the prejudices in question was against, as Schuyler's mother of ten voiced, uneducated Southern black migrants who moved to the north and became ardent Democrats in the process. Like so many African Americans in the North of this period, Schuyler had internalized the idea held by both the American mainstream and his own family that African American folk culture, which had migrated up north, was culturally unsophisticated to the point of primitivism. Schuyler, therefore, resented the notion that he shared anything in common with this culture, including a compulsory political orientation. It is no surprise then that in the 1920s he also resented those writers and 
artists of the Harlem Renaissance who celebrated African American folk culture and its left-leaning political views. It was Schuyler himself who penned the infamous article in the Nation entitled "The Negro-Art Hokum" wherein he claimed the reason African Americans were not congenitally disposed to produce inferior art forms was because "the Aframerican is merely a lampblacked AngloSaxon [sic]" (97); as simply Anglo-Saxons with darker skin, he argued, African Americans did not actually have a distinctive culture different from that of mainstream American culture. Not surprising, Schulyer's conclusion was not shared by many other African American writers of his time and it was in response to this article that Langston Hughes wrote his famous essay "The Negro Artist and the Racial Mountain."

Significantly, Schuyler had solid credentials in the African American literary world: he had been the roommate of Wallace Thurman (where both lived in the rooming house dubbed "Niggerati Manor" in Thurman's Infants of the Spring), had praised some of Hughes's writing (despite the aforementioned critical essay), and had been complimentary about W.E. B. DuBois's novel Dark Princess. But in an effort to stress his independent thinking and escape "minority" classification, he also separated himself from the leading African American writers of the day, most notably, by lampooning many of them-notably DuBois-in his novel Black No More and earlier works of fiction, and criticizing their political views in his many essays. It was thus a comparatively short step from this to Schuyler becoming the conservative voice of the African American Courier distinguishing himself enough from his peers to attract the notice and admiration of conservative members of the white literary establishment, such as $\mathrm{H}$. L. Mencken; in fact, for a while, Schuyler was referred to as "the black Mencken," in a nod to the journalist's cutting satirical style which Schuyler employed in his own writings, a compliment that nevertheless consigned him to a literary sub-category. 
Schuyler's determination to construct himself as an anti-stereotype of the unsophisticated black American continually illustrated the extent to which he had internalized the values of white America in his own quest to assert his value as a black American, often leading to some stereotypical and reductive thinking of his own: his notion of the "Aframerican" as simply a "lampblacked Anglo-Saxon" is very similar to Huck's verdict of Jim in Huckleberry Finn, specifically when Huck proclaims of Jim: "I knowed he was white inside" (Twain 251). The difference, of course, was that Twain was being deliberately ironic. But the misguided notion that a superior kind of African American could emerge by overcoming his or her so-called blackness to reveal an interior made up of desirable white qualities was all the more marked in Schuyler's thinking during these years, particularly in how he raised his daughter, Philippa.

He had married Josephine Cogdell, a white woman, who in 1931 gave birth to Philippa, an occasion reported in all the African American newspapers. Soon, Philippa made many appearances in the press when she was deemed to be a musical and intellectual prodigy, and much later the subject of her own biography. Josephine attributed her daughter's genius to a raw food diet and, more importantly, miscegenation, which Josephine believed was source of "hybrid energy." She and George began entering their daughter in every available music contest, generally making a spectacle of her. In one of Josephine's notes about these contests, quoted in Philippa's biography, she illustrates that Schuyler had found a partner who shared in his deliberately iconoclastic outlook: "[B]ecause we have refused to be conventional in our way of life, opportunity will not come to us unsought. We must seek the best for you, go out and get it or it will pass us by. We, and especially you, are a challenge to the set notions of America on race. ... Only genius will break them down, and that you have. So I take you about as much for the education of America as 
for the education of Philippa" (qtd. in Talalay 53). While Josephine was using their daughter as an educational tool, Schuyler was using his press connections to get her coverage in mainstream publications such as Time and Look; the fact that she turned out to be a beauty made his task that much easier.

Despite all her gifts, however, Philippa was not a happy child and as an adult was prone to depression. She was acutely conscious from an early age of the extent to which she was being manipulated and displayed, in her words, as a "puppet," and thus never allowed to think of herself beyond racial terms. Her biographer says, "Philippa's primary identification was largely with the white world, even when it reached her via the black intelligentsia. Her precocity was fed on notions and conceits of the white milieu" (Talalay 94), and as part of this process she had absorbed and endorsed her father's conservatism. As a young adult Phillipa lived, for the most part, overseas trying on different racial identities. Though she was largely influenced by the white world, her celebrity had been as an African American prodigy, and while she felt tied to both worlds, she discovered that abroad she was often perceived as being what today would be recognized as something closer to Latina or Asian: "A significant number of people had told her... that she did not look Negro at all but rather southern European, Levantine, Indian, or Oriental" (222). She found that this racial ambiguity gave her a sense of freedom she could not find in segregated America, which she largely abandoned for Europe in order to pursue her career. She later wrote: "I encountered vicious barriers of prejudice in the field of employment [in the U.S.] because I was the off-spring of what America calls a 'mixed marriage' . . . But instead of breaking under the strain, I adjusted to it. I left" (qtd. in Talalay 112).

She obtained a new passport, and for a while "passed" in Europe under the name Felipa Monterro y Schuyler, suggesting a Latin heritage. When her father wrote 
an essay about her for his (never-published) book The Negro in America, she furiously wrote from Europe to her mother claiming, "I am not a Negro, and won't stand for being called one in a book that will circulate in countries where that taint has not been applied to me. It makes all future effort on my part to forge a worthwhile niche for myself in society where I will be accepted as a person not a strange curiosity useless" (qtd. in Talalay 224). Because she could fit into almost any ethnic category in Europe, she chose to be accepted on her merits as a musician and a woman, not as a "curiosity" or token as she found in America. Schuyler's own contrarianism in matters of race exacerbated her discomfort and ultimately undermined their relationship, as her father went much further in political terms than Philippa was prepared to go. As the century wore on, he spoke out against the Civil Rights movement, against Dr. Martin Luther King Jr. being awarded the Nobel Peace Prize, and against African independence, all of which Schuyler regarded as nothing more than communist conspiracies. As Philippa noted: "My father's way-out extreme right conservatism has been an extra factor in segregating me. For some reason, he has chosen to be politically on the same side of the fence as the most prejudicial whites [in America]" (qtd. in Talalay 262).

Schuyler's willingness to adopt any perspective other than that expected of him, and to prove his daughter not to be what was expected of her, shows the extent to which he had turned the definition of conservative inside out, arguing both against the status quo (wanting respect as a black American) and against changing it (wanting respect as a quasi-white American). It is a reminder of how bound up in the meaning of the word politic is the word expedient; Schuyler found himself in the same position as many minorities that preceded him but was willing to take the most expedient road to racial advancementeven if it meant having to consort with the enemy. As his life and career progressed, it appears that Schuyler 
never recognized his political contradictions, even if his daughter, whose advancement he tried so elaborately to orchestrate, eventually did. Soon after Schuyler had published an article blaming the Watts riots on Dr. King "infecting the mentally retarded with the germs of civil disobedience" [qtd. in Williams 171]), The Crisis wrote: "Mr. Schuyler does not even comprehend the depth and fury of the Negro's resentment against the restrictions imposed upon him solely because of his race. All in his years [sic], Mr. Schuyler has been too busy breaking idols to learn this lesson" (qtd. in Williams 171). Yet it was not so much that Schuyler did not comprehend things as much as he repressed such comprehension, deliberately focusing on issues elsewhere when it was to his advantage. He had suffered from Jim Crow like everybody else, and knew exactly how it felt, but he also knew-he thought-a way out of it: the most expedient, if not the most consistent, way.

The satirical novel for which he is best known, Black No More (1931), is a story that deals with the issue of pure opportunism, racial and otherwise, and as such, it is difficult to pin down its politics, more evidence, it could be argued, of Schuyler's own conflicted thinking. The plot revolves around the discovery of a technique to turn black skin white through the escapades of Max Disher, a black American who becomes Matthew Fisher, a white American, after being told one night by a beautiful white girl in a Harlem club, "I never dance with niggers!" (8). Disher's decision to take a color-changing treatment is purely for self-interest; it has less to do with ideology than with satisfying his lust. He goes home and dreams of "sitting beside her on a golden throne [presumably sharing her white attributes] while millions of manacled white slaves prostrated themselves before him" (9). But then, curiously, Disher has a nightmare about a lynching. It seems very simple to him: who would not want to be white under such circumstances? The white scenario appears to be clearly a positive one, where power 
is conferred and ultimate power is possible, so Disher naturally rejects blackness and becomes white (and then, contrary to most stereotypes, he is able to dance).

Although Disher immediately takes the "Black No More" treatment and the rest of the story is told from his transformed perspective, it is not easy to discern Schuyler's attitude toward his protagonist. Ostensibly the hero, by the fourth line of the story, Disher's features are nevertheless described as having "a slightly satanic cast" (3) and, as quoted above from the first chapter, he fantasizes about slaves-in this case, white ones. Max's fantasy of white slaves suggests that the world he is trying to join would simply be an inverted version of the world he currently inhabits, so that (although he never consciously thinks of it this way) one side of the color line remains a negative reflection of the other. Moreover, other aspects of the narrative suggest an even more unstable and incoherent racial perspective. The world of Black Harlem, for example, is one that Max finds more valuable and authentic than that of white society where "joy and abandon... was obviously forced" (22). Yet, it is the latter world that Disher is intent on joining. Ultimately, the protagonist is actually rewarded by his black author for becoming white by achieving the girl of his dreams. As a whole, the narrative, in terms of its racial perspective, is inconsistent and illogical.

One might forgive the narrative's illogical inconsistencies due to the fact that the text is formally presented as satire, but satire too requires a stable viewpoint from which to make certain arguments. One example of a narrative wherein the attitude appears to shift is when Max, or Matthew, as he has since become, realizes that since everybody has become white, the easiest way to cash in is to become a leader of the white supremacist group, the Knights of Nordica. Despite his loathing of the "white masses" he was originally so eager to join, this decision makes satirical sense since he plans to "use them as a stepladder to the real money" (49). At 
the end of the story, the entire issue of race discrimination is reversed as statistics are published that argue that the whiter a person's skin, the more likely that he or she was once originally black; in fact, as it turns out, all the Nordica leadership is revealed as having some African ancestry. Disher consequently flees the country with the rest of the Nordica leadership. In their departure, his old friend Bunny brings along his new and authentically black wife: "'She must be the last black gal in the country,' Matthew remarked, glancing enviously at his friend. ... 'She's a race patriot,'" Bunny responds (156). Matthew's bewildered response nevertheless reveals a simultaneous envy of his friend, who ultimately resists "Black No More." In Schulyer's novel, race pride mingles with race rejection in much the same way that prominent African American leaders are lampooned in the book along with organizations like the NAACP. The last "set piece" in the book is a savage satire of a lynching, whose brutality and savagery, even as a subject for "black" humor, in 1931 was a risky and perilous strategy for a writer to take. Its inclusion, however, illustrates perfectly Schuyler's desire to both castigate extreme behavior by some white Americans while simultaneously mocking the extremes of race pride among black Americans. In the scene, white characters are lynched because they are so white that nobody believes they were not originally black, and, in fact, they do have distant African American ancestry. Thus, ironically, apparent whites lynch other apparent whites for being black. The ludicrousness of the situation underscores Schuyler's point, which he aims at both races: racial discrimination of all kinds is senseless; and, as a corollary, from Schuyler's perspective, so are the virtues of miscegenation. At the end of Black No More, he writes: "Everybody that was anybody had a stained skin... America was definitely, enthusiastically mulattominded" (179). Even this, however, is a sardonic point as the book ends when a character spots a photograph of Max and his extended family in the newspaper, all now 
looking notably "dusky" (180). Color is therefore remains a cause for discrimination, except now it is fashionable to be dark, and Max has once again cashed in on the winning side.

Max, the supreme opportunist whose feelings about his own race, and race as a concept, virtually changes on every page, and as such, is an apt reflection, at least partly, of his creator's psyche-as was the daughter he raised to benefit from both aspects of her mixed racial background. Schuyler knew what it was to be pigeonholed and did everything in his power to escape it. As the historian John Henrik Clarke writes, "George got up in the morning, waited to see which way the world was turning, then struck out in the opposite direction. He was a rebel who enjoyed playing that role" (qtd. in BNM vii). This made Schuyler, paradoxically, a non-conservative conservative-one who "played" the conservative role then eventually came to believe in its ideology to the point of extremism, out of expediency. Schuyler deconstructs the whole conservative narrative without supplying a constructive alternative, other than his anti-communism; his message was largely about what he did not want to be, either personally or professionally. He eventually drifted out of the mainstream, out of his job at the Courier, and into the arms of white ultraconservative organizations such as the John Birch Society, never achieving the broad success his considerable talents promised. His private life fared no better: Philippa died at age 35 in a plane crash in Vietnam, where she was working as a journalist, and his wife Josephine hung herself two years later-Schuyler outlived her by eight years.

The ultimate irony of George S. Schuyler is that, when it came to matters of racial categorization, he was, in many respects, correct. On the last page of his autobiography, he writes that, "At best, race is a superstition" (352). His was an early and often lonely fighter against essentialism, against outdated and untenable notions of race as perceived by both sides of the "color line." Hence, he was 
not surprised at the difficulty with which black Americans overcame preconceptions, as he probably would not have been surprised that an African American candidate for office could one day be described as "not black enough." Yet his story also illustrates the tragic consequences that only an intense awareness of double consciousness could produce. As Oscar R. Williams has said, "Schuyler constantly warred with his twoness, struggling to be part of the American mainstream while trying to resist the call of his African American contemporaries to join the struggle. In the end, Schuyler chose to be American, sacrificing his identity and, eventually, his family" (174). Of course, the whole point is that he was an Americanbut in claiming this identity, he felt he had to deny any specific racial solidarity, causing him to be regarded by many of his fellow African Americans as a traitor.

It is difficult to understand how an African American like Schuyler, who had grown up in the Jim Crow era, could be persuaded, or rather persuade himself, that the Civil Rights movement had actually made conditions worse for minority Americans. But his story makes it all too clear how vulnerable such embattled Americans could be to the lure of extreme conservatism. Ultimately, his attraction was not to an ideology per se, which had to be considerably distorted if it was to fit a decidedly minority viewpoint, but to the promise of individualist conservatism preached. This is why his story remains pertinent, both as a warning against such vulnerability, and also against the counter-productiveness of stereotyping, political and otherwise. 


\section{Works Cited}

Anon. Bibliographical note. Black No More. By George S. Schuyler. New York: Random House, 1999.

Hughes, Langston. "The Negro Artist and the Racial Mountain." The Nation, June 23,1926. Rpt. in The Portable Harlem Renaissance Reader. Ed. David Levering Lewis. New York: Penguin, 1994. 91-95.

Schuyler, George S. Black and Conservative. New York: Arlington House, 1966.

---. Black No More. 1931. New York: Random House, 1999.

--.. "The Negro-Art Hokum." The Nation, June 16, 1926. Rpt. in The Portable Harlem Renaissance Reader. Ed. David Levering Lewis. New York: Pengion, 1994. 96-99.

Talalay, Kathryn. Composition in Black and White: The Life of Philippa Schuyler. New York: OUP, 1995.

Twain, Mark. Adventures of Huckleberry Finn. 1885. Rpt. in "Adventures of Huckleberry Finn": A Case Study in Critical Commentary. Ed. Gerald Graff and James Phelan. New York: Bedford, 1995. 27-265.

Williams, Oscar R., Jr. "The Lonely Iconoclast: George Schuyler and the Civil Rights Movement." Dimensions of Black Conservatism in the United States. Ed. Gayle T. Tate and Lewis A. Randolph. New York: Palgrave, 2002. 163-178. 